\title{
Distribution of Valence States of Recoil Antimony Atoms in Inorganic Compounds
}

\author{
Tomihisa Kambara, Nobuyuki Kashinira, \\ Katsuyuki Hagita and Chung-huei Ke* \\ Radiochemistry Research Laboratory, Shizuoka University, \\ *Tsing Hua University (Taiwan) \\ Received March 9, 1965
}

\begin{abstract}
Potassium antimonate was irradiated with thermal neutrons to investigate the distribution of recoil antimony atoms between the tri-and pentavalent states. The retention values were found to be decreased linearly with the decrease of the amounts of crystalline water in the compound. It may be supposed that the $\mathrm{OH}$ radical in the crystal may play an important role on the valence states of recoil antimony atoms.

This supposition might be reasonable as compared with the results obtained for the antimony exchange reaction in a heterogeneous system (liq.-solid system).
\end{abstract}

\section{Introduction}

As to the study of antimony recoil chemistry, T. Andersen, et al. ${ }^{1)}$ and J.F. Facet $\mathrm{ti}^{2}{ }^{2}$ investigated the distribution of valence of recoil antimony atoms formed by the thermal neutron irradiation of potassium antimonate. It has been found by J.F. Facetti ${ }^{2}$ that the ratio of oxygen atoms to antimony atoms in the compound is the main factor in determining the distribution of the radioactive antimony between the tri- and pentavalent states.

In the present work, the values of the retention were investigated on the neutron irradiated potassium antimonate using both the C.P. reagent (Wako Co., Ltd.) and the synthesized compound, and effects of the crystalline water on the retention of $* \mathrm{Sb}(\mathrm{V})$ were investigated.

\section{Experimental}

\subsection{Material and Reagents}

Material: Two sorts of potassium antimonate compounds were used; (A) the C.P. "potassium pyro-antimonate" (Wako Co., Ltd. reagent), without further purification, (B) KSb $(\mathrm{OH})_{6}$ synthesized according to the method of Brauer $^{3 \text {. }}$.

These samples were submitted to the following pre-irradiation treatments.

(1) Samples $A_{1}$ and $B_{1}$ were used without pre-treatment.

(2) Samples $A_{2}$ and $B_{2}$ were heated at $290 \pm$ $5^{\circ} \mathrm{C}$ for $12 \mathrm{hrs}$.

(3) Samples $A_{3}$ and $B_{3}$ were heated at $290 \pm$ $5^{\circ} \mathrm{C}$ for $24 \mathrm{hrs}$.

Antimony tracer: ${ }^{124} \mathrm{Sb}$ obtained from Oak Ridge National Laboratory (U.S.A.) was used for the studies of the exchange reaction. It was a Processed Unit and the chemical form was antimony (III) chloride in a hydrochloric acid solution.

Other reagents: The isopropyl ether used for extraction was of reagent grade extra pure and purified by distillation. It was made free from peroxide by shaking repeatedly with ferrousammonium sulfate solution acidified with sulfuric acid. Other chemicals were of reagent grade extra pure and used without further treatment.

\section{$2 \cdot 2$ Irradiation}

The samples were irradiated for 5 minutes in the JRR-1 or JRR-2 nuclear reactor with thermal neutron flux of $4 \times 10^{11}$ or $4 \times 10^{13}$ neutrons $\cdot \mathrm{cm}^{-2} \cdot \mathrm{sec}^{-1}$, respectively*.

\subsection{Chemical procedure and counting}

The irradiated samples were dissolved in $6 \mathrm{~N}$ hydrochloric acid containing both the $\mathrm{Sb}(\mathbb{I})$ and $\mathrm{Sb}(\nabla)$ carriers. For separating ${ }^{*} \mathrm{Sb}(\nabla)$ and $* \mathbf{S b}(\mathbb{I I})$ from each other the isopropyl ether extraction method used by N.A. Bonner ${ }^{4)}$

* Some preliminary investigations were made by the use of the reactor of Tsing Hua University of Taiwan. 
was applied. The activities both in the acid layer and in the ether layer were measured with the scintillation counter*. From both activities the retention of $* \mathbf{S b}(\nabla)$ was calculated.

A single channel pulse-height analyser** was used to determine the nuclides formed by the neutron capture process. A peak of about $0.6 \mathrm{MeV}$ was observed $\left({ }^{122} \mathrm{Sb}\right.$ : $0.57 \mathrm{MeV} ;{ }^{124} \mathrm{Sb}$ : $0.60 \mathrm{MeV}$ ). Measuring the decay of the ir- radiated sample by the G-M counter ${ }_{*}^{* *}$, the half-life of the major activity was found to be 2.8 days (of ${ }^{122} \mathrm{Sb}$ ) and that of the residual activity was found to be 60 days (of ${ }^{124} \mathrm{Sb}$ ).

\section{Results}

\section{$3 \cdot 1$ Retention of $\mathrm{Sb}(\nabla)$}

The tables 1 and 2 show the results on the distribution of recoil antimony atoms between tri- and pentavalent states.

It can be seen that the distribution of the

Table 1 Retention values of $* \mathrm{Sb}(\nabla)$ in the sample A

\begin{tabular}{|c|c|c|c|c|c|c|}
\hline $\begin{array}{l}\text { Sample } \\
\text { No. }\end{array}$ & $\begin{array}{l}\text { Preirradiation } \\
\text { treatment }\end{array}$ & $\begin{array}{c}* \mathrm{Sb}(\mathbb{I I}) \\
(\%)\end{array}$ & $\underset{(\%)}{* \operatorname{Sb}(\nabla)}$ & $\begin{array}{l}\text { Retention of } \\
* \mathrm{Sb}(\nabla) \text { aver } \\
(\%)\end{array}$ & $\begin{array}{l}\text { Irradiation } \\
\text { time (min) }\end{array}$ & $\begin{array}{l}\text { Neutron flux } \\
\left(\mathrm{n} \cdot \mathrm{cm}^{-2} \cdot \mathrm{sec}^{-1}\right)\end{array}$ \\
\hline$A_{1}$ & None & $\begin{array}{l}12.6 \\
13.6\end{array}$ & $\begin{aligned} 87.4 \\
86.4\end{aligned}$ & $86.8 \pm 0.4$ & 5 & $4 \times 10^{13}$ \\
\hline $\mathrm{A}_{2}$ & $\begin{array}{c}290 \pm 5^{\circ} \mathrm{C} \\
12 \mathrm{hrs} .\end{array}$ & $\begin{array}{l}34.7 \\
33.1 \\
34.1\end{array}$ & $\begin{array}{l}65.3 \\
66.9 \\
65.7\end{array}$ & $66.0 \pm 4.3$ & 5 & $4 \times 10^{11}$ \\
\hline $\mathrm{A}_{3}$ & $\begin{array}{c}290 \pm 5^{\circ} \mathrm{C} \\
24 \text { hrs. }\end{array}$ & $\begin{array}{l}30.8 \\
31.3 \\
36.6\end{array}$ & $\begin{array}{l}69.2 \\
68.7 \\
63.4\end{array}$ & $67.1 \pm 4.3$ & 5 & $4 \times 10^{11}$ \\
\hline
\end{tabular}

Table 2 Retention values of ${ }^{*} \mathrm{Sb}(\nabla)$ in the sample B

\begin{tabular}{|c|c|c|c|c|c|c|}
\hline $\begin{array}{c}\text { Sample } \\
\text { No. }\end{array}$ & $\begin{array}{l}\text { Preirradiation } \\
\text { treatment }\end{array}$ & $\begin{array}{c}* \mathrm{Sb}(\mathbb{I I}) \\
(\%)\end{array}$ & $\begin{array}{c}* \operatorname{Sb}(\mathrm{V}) \\
(\%)\end{array}$ & $\begin{array}{l}\text { Retention of } \\
{ }^{*} \mathrm{Sb}(\nabla) \text { aver } \\
(\%)\end{array}$ & $\begin{array}{l}\text { Irradiation } \\
\text { time (min) }\end{array}$ & $\begin{array}{l}\text { Neutron flux } \\
\left(\mathrm{n} \cdot \mathrm{cm}^{-2} \cdot \mathrm{sec}^{-1}\right)\end{array}$ \\
\hline $\mathrm{B}_{1}$ & None & $\begin{array}{l}15.0 \\
14.6 \\
14.9\end{array}$ & $\begin{array}{l}85.0 \\
85.4 \\
85.1\end{array}$ & $85.2 \pm 0.6$ & 5 & $4 \times 10^{13}$ \\
\hline $\mathrm{B}_{2}$ & $\begin{array}{c}290 \pm 5^{\circ} \mathrm{C} \\
12 \mathrm{hrs} .\end{array}$ & $\begin{array}{l}53.1 \\
56.2 \\
56.8 \\
53.4\end{array}$ & $\begin{array}{l}46.9 \\
43.8 \\
43.2 \\
46.6\end{array}$ & $45.1 \pm 9.8$ & 5 & $4 \times 10^{11}$ \\
\hline $\mathrm{B}_{3}$ & $\begin{array}{c}290 \pm 5^{\circ} \mathrm{C} \\
24 \mathrm{hrs} .\end{array}$ & $\begin{array}{l}56.2 \\
57.8 \\
58.4\end{array}$ & $\begin{array}{l}43.8 \\
42.2 \\
41.6\end{array}$ & $42.5 \pm 3.0$ & 5 & $4 \times 10^{11}$ \\
\hline
\end{tabular}

valence of the radioactive antimony depends upon the duration of the pre-irradiation treatment. This tendency shows a good agreement with the results given by J.F. Facetti ${ }^{2)}$. Also it can be seen that the retention of $* \mathrm{Sb}(V)$ for the non-treated samples shows higher values than the previously published data $^{1,2}$.

\subsection{Crystalline water in $\mathrm{KSbO}_{3} \cdot \mathrm{xH}_{2} \mathrm{O}$}

Potassium antimonate can be expressed by the compositional formula $\mathrm{KSbO}_{3} \cdot \mathrm{xH}_{2} \mathrm{O}_{* *}^{* *}$. The tables 3 and 4 show the amounts of the crystalline water ${ }_{* *}^{* * *}$.

3.3 Relation between retention and crystalline water

By plotting the retention of $* \operatorname{Sb}(\nabla)$ versus the amounts of the crystalline water, a linear relation was obtained as shown in the Fig. 1.

3.4 Isotopic exchange reaction in heterogeneous system (liq.-solid system)

The effects of $\mathrm{HCl}$ concentration on the exchange rate between $\mathrm{Sb}(\mathbb{I})$ in the $\mathrm{HCl}$ solution and $\mathrm{Sb}(\nabla)$ in $\mathrm{KSb}(\mathrm{OH})_{6}$ precipitates

* JRC Co., Ltd. made, using NaI crystal as a scintillator

** Detectolab. Products made

** JRC Co., Ltd. made

** J.F. Facetti ${ }^{2}$ expressed the formula of potassium antimonate pre-treated at a high temperature as the hypothetical formula $\mathrm{KSbO}_{3}$.

*** The amounts of the crystalline water were calculated from the gravimetric antimony determination by the modified sulfide method $^{5)}$. 
Table 3 Results of antimony analysis and of crystalline water calculation in the sample A

\begin{tabular}{c|c|c|c|c|c|c}
\hline $\begin{array}{c}\text { Sample } \\
\text { No. }\end{array}$ & $\begin{array}{c}\mathrm{KSb}(\mathrm{OH})_{6} \\
(\mathrm{mg})\end{array}$ & $\begin{array}{c}\text { ppt. of } \mathrm{Sb}_{2} \mathrm{~S}_{3} \\
(\mathrm{mg})\end{array}$ & $\begin{array}{c}\text { Sb found } \\
(\mathrm{mg})\end{array}$ & $\begin{array}{c}\mathrm{Sb}(\%) \text { in } \\
\mathrm{KSbO}_{3} \cdot \mathrm{xH}_{2} \mathrm{O}\end{array}$ & crystalline & water \\
\hline & 72.8 & 43.6 & 31.3 & 42.9 & 4.16 & \\
\hline \multirow{2}{*}{$\mathrm{A}_{1}$} & 72.5 & 43.0 & 30.8 & 42.5 & 4.31 & 4.24 \\
& 41.8 & 25.1 & 18.0 & 43.1 & 4.08 & 3.01 \\
$\mathrm{~A}_{2}$ & 49.7 & 34.6 & 24.8 & 49.9 & 1.95 & \\
& 56.0 & 40.9 & 29.3 & 52.4 & 1.33 & 1.40 \\
$\mathrm{~A}_{3}$ & 50.3 & 36.3 & 26.0 & 51.7 & 1.48 & \\
\hline
\end{tabular}

Table 4 Results of antimony analysis and of crystalline water calculation in the sample B

\begin{tabular}{|c|c|c|c|c|c|c|}
\hline \multirow{2}{*}{$\begin{array}{c}\text { Sample } \\
\text { No. }\end{array}$} & \multirow{2}{*}{$\begin{array}{c}\mathrm{KSb}(\mathrm{OH})_{6} \\
(\mathrm{mg})\end{array}$} & \multirow{2}{*}{$\begin{array}{l}\text { ppt. of } \mathrm{Sb}_{2} \mathrm{~S}_{3} \\
(\mathrm{mg})\end{array}$} & \multirow{2}{*}{$\begin{array}{l}\text { Sb found } \\
\text { (mg) }\end{array}$} & \multirow{2}{*}{$\begin{array}{l}\mathrm{Sb}(\%) \text { in } \\
\mathrm{KSbO}_{3} \cdot \mathrm{xH}_{2} \mathrm{O}\end{array}$} & Crystalline & water \\
\hline & & & & & $(\mathrm{x})$ & aver. \\
\hline $\mathrm{B}_{1}$ & - & - & - & - & - & - \\
\hline $\mathrm{B}_{2}$ & $\begin{array}{l}50.5 \\
50.2\end{array}$ & $\begin{array}{l}35.4 \\
36.5\end{array}$ & $\begin{array}{l}25.4 \\
26.2\end{array}$ & $\begin{array}{l}50.3 \\
52.2\end{array}$ & $\begin{array}{l}1.84 \\
1.35\end{array}$ & 1.60 \\
\hline $\mathrm{B}_{3}$ & $\begin{array}{l}50.8 \\
50.4\end{array}$ & $\begin{array}{l}37.4 \\
37.9\end{array}$ & $\begin{array}{l}26.8 \\
27.1\end{array}$ & $\begin{array}{l}52.8 \\
53.8\end{array}$ & $\begin{array}{l}1.20 \\
0.97 \\
\end{array}$ & 1.09 \\
\hline
\end{tabular}

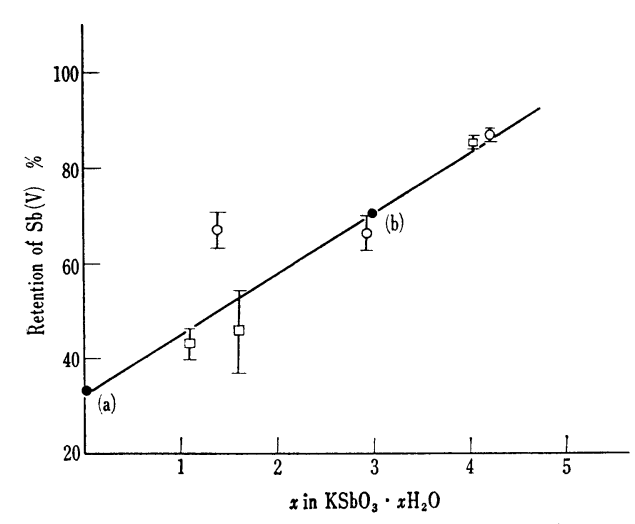

- : (a) is retention value for $\mathrm{KSbO}_{3}(32.9 \%$ from J.F. Facetti)

(b) is retention value for $\mathrm{KSbO}_{3} \cdot 3 \mathrm{H}_{2} \mathrm{O}$ $\left(=\mathrm{KSb}(\mathrm{OH})_{6}\right.$, about $70 \%$ from $\mathrm{T}$. Andersen, et al. and J.F. Facetti)

호: Retention values of C.P. compounds

모: Retention values of synthesized compounds

Fig. 1 Variation of retention with the changes of amounts of crystalline water.

were investigated for the help of understanding the results obtained above*. The results are given in the Fig. 2. It can be seen that the amounts exchanged become smaller in proportion as the acidities increase. At $6 N \mathrm{HCl}$ the added $* \mathrm{Sb}(\mathbb{I})$ activity was found to be almost unexchanged.

\section{Discussion}

Summarizing the authors' retention values and T.Andersen and others' values ${ }^{1,2)}$, a linear

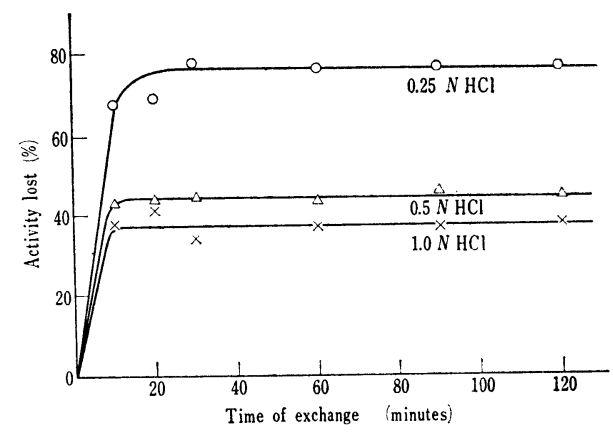

Fig. 2 Isotopic exchange between $* \mathrm{Sb}(\mathbb{I})$ and $\mathrm{Sb}(V)$ in solid-liquid systems.

relation was observed between the retention and the amounts of crystalline water. This linearity indicates that the crystalline water in the compound affects strongly the distributions of valence of the recoil atoms. The exchange ratios in the heterogeneous system as mentioned above were found to be increased with the decrease of $\mathrm{HCl}$ concentrations, i. e. the increase of $\mathrm{OH}^{-}$concentrations. From the results obtained for antimony exchange in $\mathrm{Sb}(\mathbb{I I})$ $\mathrm{KSb}(\mathrm{OH})_{6}$ system, it can be seen that $\mathrm{OH}^{-}$ion might have a promoting action for $\mathrm{Sb}(\mathbb{I})-\mathrm{Sb}$ $(\nabla)$ exchange. Analogously for the authors' results obtained with solid $\mathrm{KSb}(\mathrm{OH})_{6} \cdot \mathrm{xH}_{2} \mathrm{O}$,

* Mixing $\mathrm{KSb}(\mathrm{OH})_{6}$ with the $\mathrm{HCl}$ solution containing ${ }^{124} \mathrm{Sb}(\mathbb{I I})$ at the room temperature, the changes of the activities of the supernatant were measured with the lapse of time by a scintillation counter. 
$\mathrm{OH}^{-}$may play an important role for the change of the retention values, which was found that the retention values are increased linearly with the increase of the amounts of crystalline water.

The more extended studies on the relations between the retention values and the chemical structure are thought to be necessary in future.

Acknowledgement; The authors wish to express their thanks to the Ministry of Education and also to the Institute of Atomic Energy Education of Tokyo University for the defra- yments of a part of the expense for this work.

\section{References}

1) T. Andersen and A.B. Knutsen: J. Inorg. Nucl. Chem., 23, 191 (1961)

2) J.F. Facetti: ibid., 25, 759 (1963)

3) G. Brauer: Handbuch der praeparativen Anorganischen Chemie, p.1255 Ferdinand Enke Verlag, Stuttgart (1954)

4) N.A. Bonner: J. Am. Chem. Soc., 71, 3909 (1949)

5) T. Kambara: Radioisotopes, 7, 112 (1958)

要旨

\section{無機化合物における反跳アンチモン原子の原子価分布}

神原富尚，柏平伸幸，萩田勝之，柯烟輝*

静岡大学放射化学研究施設, *清華大学（台湾）

アンチモン酸カリウムを熱中性子で照射したさいに生ずる反跳アンチモン原子の原子価分布をし らべた。市販怙よび合成したアンチモン酸カリウムの反跳アンチモン原子のリテンション值は, 化 合物の中性子照射前の熱処理を増すにつれ，すなわち，化合物中の結合水が減少するにつれて直線 的に低くなることがわかった。これは結晶中で結合水の $\mathrm{OH}$ が促進的に作用してリテンション值を 高めるためと推定された。この事実は, 異相系（液一固）の交換反応の結果からも十分類推するこ とができる。 